\title{
Assessment of the Morphological, Biochemical, and Kinetic Properties for Candida rugosa Lipase Immobilized on Hydrous Niobium Oxide to Be Used in the Biodiesel Synthesis
}

\author{
Michele Miranda, ${ }^{1}$ Daniele Urioste, ${ }^{1}$ Livia T. Andrade Souza, ${ }^{1}$ \\ Adriano A. Mendes, ${ }^{2}$ and Heizir F. de Castro ${ }^{1}$ \\ ${ }^{1}$ Engineering School of Lorena, University of São Paulo, P.O. Box 116, 12602-810 Lorena, SP, Brazil \\ ${ }^{2}$ Laboratory of Biocatalysis, Federal University of São João del Rei, P.O. Box 56, 35701-970 Sete Lagoas, MG, Brazil \\ Correspondence should be addressed to Heizir F. de Castro, heizir@dequi.eel.usp.br
}

Received 15 April 2011; Accepted 27 May 2011

Academic Editor: Alane Beatriz Vermelho

Copyright (C) 2011 Michele Miranda et al. This is an open access article distributed under the Creative Commons Attribution License, which permits unrestricted use, distribution, and reproduction in any medium, provided the original work is properly cited.

Lipase from Candida rugosa (CRL) was immobilized by covalent attachment on hydrous niobium oxide. The matrix could effectively be attached to the enzyme with high retention of activity and prevent its leakage. Following immobilization, CRL exhibited improved storage stability and performed better at higher incubation temperatures. In addition, the enzyme retained most of its catalytic efficiency after successive operational cycles. The immobilized derivative was also fully characterized with respect to its morphological properties: particle size, surface specific area, and pore size distribution. Structural integrity and conformational changes, such as surface cavities in the support, set by the lipase procedure, were observed by Scanning Electron Microscopy. Additionally, a comparative study between free and immobilized lipases was provided in terms of $\mathrm{pH}$, temperature, and thermal stability. CRL derivative was evaluated for the synthesis of biodiesel employing babassu oil and short chain alcohols. The process was feasible only for oil and butanol reaction system.

\section{Introduction}

Investigations of alternative renewable energy resources continue, with many studies focused on biodiesel fuels. One of the alternative renewable energy sources for diesel engines is vegetable oil. Studies have shown that pure vegetable oils are not a suitable direct replacement for diesel fuel, due to higher viscosity and molecular weight [1]. These properties cause incomplete combustion and engine deposits [2]. Therefore, several methods are used to reduce the viscosity of vegetable oil, such as transesterification reaction [3]. The transesterification reaction involves the reaction of alcohol with the oil, releasing glycerol as byproduct and monoalkyl esters (biodiesel), an excellent substitute for fossil fuels. In this reaction, alkali or acid are typically used as the catalysts resulting in high conversion levels in short reaction time $[3,4]$. However, there are major drawbacks of such chemical process, as several problems during the steps of removal of catalyst from the product, recovery of glycerol, and the alkaline wastewater treatment, and interference of free fatty acid and water in the reaction and excessive consumption of energy $[3,4]$. The use of heterogeneous catalysts, including immobilized lipases can overcome these problems which allow mild reaction conditions and no generation of chemical waste [3-7].

Lipases (E.C. 3.1.1.3) are ubiquitous enzymes with various biological activities, including triacylglycerols hydrolysis, esterification between fatty acid (FA) and alcohol, and other enzymatic reactions $[8,9]$. Among the lipases from various sources, Candida rugosa lipase (CRL) received much attention due to its high activity and broad specificity [10, 11]. Published studies have demonstrated that CRL can be activated by interactions with a hydrophobic interface because of its conformational changes in its secondary structure (termed the "lid") [11]. In the absence of a hydrophobic interface, the "lid" covers its active site and makes 
it inaccessible to substrates, whereas the conformational changes induced by interacting with the hydrophobic interface can yield an "open structure" of the lipase [12-14]. Thus, creating a hydrophobic microenvironment provides a preferable way to activate the lipase. Immobilization of lipase is expected to provide this hydrophobic microenvironment [13]. Moreover, enzyme immobilization provides a favorable approach to easy enzyme recovery for its recycled use and to extend its half-life. Thus, exploiting good immobilization carriers has been an attractive work for enzyme engineering.

In this context, new inorganic matrixes as hydrous niobium oxides possess important properties of ionic exchange and show compatible affinity to be used as support for immobilizing chemical or biochemical catalysts.

Niobium is a rare, soft, malleable, ductile, gray-white metal with a body-centered cubic crystalline structure. Niobium is widely distributed in nature and it is about one and a half time as abundant as lead. It occurs in the minerals columbite and tantalite, together with tantalum. Niobium can form four oxides, from which the pentoxide, $\mathrm{Nb}_{2} \mathrm{O}_{5}$, is the basis of a series of salts called niobates and has wide applications including electronic and optical devices, special alloys, super conducting materials, and catalysts. $\mathrm{Nb}_{2} \mathrm{O}_{5}$ is also an excellent alternative for acid catalysis, acting as support, supported phase or associated with other metals (e.g., V, Pt, Mo, and W) increasing its selectivity toward many reactions. Hydrous niobium oxide is a polymeric material obtained from the hydrolysis of an intermediary product from alkaline fusion of $\mathrm{Nb}_{2} \mathrm{O}_{5}$ with an excess of $\mathrm{K}_{2} \mathrm{CO}_{3}$ [15].

In a previous work, hydrous niobium oxide was used as matrix for immobilizing the lipase from Candida rugosa by covalent binding in the presence of polyethylene glycol as stabilizing additive [16]. The immobilization conditions were established by factorial design and the resulted immobilized derivative showed considerable high hydrolytic and esterification activities that warranted the need for complementary studies concerning its morphological, biochemical, and kinetic properties. These studies are the objective of this paper.

In addition, the catalytic performance of the immobilized derivative was explored to carry out ester synthesis by direct esterification (butyl butyrate) and transesterification reaction using babassu oil (biodiesel). This oil is obtained from the kernels of the babassu palm, found in the northeast region of Brazil. It has broad application in cosmetic formulation [17-19]. The kernel contains $60-70 \%$ of a vegetable oil rich in saturated fatty acids lauric $(\mathrm{C} 12)$ and myristic (C14), similar in composition to that of coconut and the use for to biodiesel production is still scarce related in the literature.

\section{Materials and Methods}

2.1. Materials. Commercial lipase from Candida rugosa (Type VII), bovine serum albumin (BSA), and $p$-nitrophenyl palmitate ( $p$-NPP) were purchased from Sigma Chemical Co. (St Louis, MO, USA). This lipase is substantially free of other hydrolases and contains lactose as an extender. Nominal specific lipase activity was 1600 units $\cdot \mathrm{mg}^{-1}$ of solid.
Polyethylene glycol (PEG, MW 1,500, Merck, Germany) was used as stabilizing agent. $\gamma$-aminopropyltriethoxysilane ( $\gamma$-APTS) was supplied by Across Organic (New Jersey, USA) and used without further purification. Gum arabic, Triton X-100, and heptane were supplied by Synth (SP, Brazil). Babassu oil was kindly supplied by COGNIS (Cognis from Brazil Ltda., Jacareí, SP, Brazil) having the following composition in fatty acids: (w/v): $3.5 \%$ caprylic, $4.5 \%$ capric, $44.7 \%$ lauric, $17.5 \%$ myristic, $9.7 \%$ palmitic, $3.1 \%$ stearic, $15.2 \%$ oleic, and $1.8 \%$ linoleic with average molecular weight $709.90 \mathrm{~g} / \mathrm{mol}$. Solvents were standard laboratory grade (Synth, São Paulo, SP, Brazil). Substrates for esterification reactions $n$-butanol (Merck, Germany) and butyric acid (Riedel-de Häen, Germany) were dehydrated, with $0.32 \mathrm{~cm}$ molecular sieves (aluminum sodium silicate, type $13 \mathrm{X}$ BHD Chemicals, Toronto, Canada), previously activated in an oven at $350^{\circ} \mathrm{C}$ for $6 \mathrm{~h}$. Other reagents and solvents were of standard laboratory grade.

2.2. Preparation and Activation. Hydrous niobium oxide was prepared according to methodology previously established by Serafim [15] consisting of sintering niobium pentoxide with a fivefold excess by weight of potassium carbonate at $1000^{\circ} \mathrm{C}$ for $6 \mathrm{~h}$, followed by addition of hot water and nitric acid $1.0 \mathrm{M}$. The material was dried at $50^{\circ} \mathrm{C}$ for $24 \mathrm{~h}$. The support was submitted to a pretreatment with nitric acid $(1 \%)$ at $75^{\circ} \mathrm{C}$ for $1 \mathrm{~h}$ to open the matrix pores and then silanized with $\gamma$-aminopropyltriethoxysilane ( $\gamma$-APTS) and activated with glutaraldehyde at $2.5 \%$ and $\mathrm{pH} 8$ according to the procedure established by Miranda et al. [16].

2.3. Immobilization Procedure. Lipase was immobilized by covalent attachment on hydrous oxide niobium previously treated with $\gamma$-aminopropyltriethoxysilane ( $\gamma$-APTS), followed by activation with glutaraldehyde [16]. For each gram of hydrous niobium oxide (dry weight) suitable amount of enzyme $(0.25 \mathrm{~g})$ was dissolved in distilled water and mixed with the support under low stirring during $3 \mathrm{~h}$ at room temperature. After this, $10 \mathrm{~mL}$ of hexane was added to the mixture enzyme support and the coupling took place overnight at $4^{\circ} \mathrm{C}$. The derivative was filtered (Whatman filter paper 41) and thoroughly rinsed with hexane. Analyses of the hydrolytic activities carried out on initial and spent lipase solutions and immobilized preparations showed high level of lipase recovery on the support $(\eta=47.5 \%)$.

2.4. Surface Area Determinations. The surface area measurements were performed by adsorption using nitrogen as adsorbate. The samples were previously degassed to below $50 \mathrm{mmHg}$ at room temperature and the analyses were performed at $77 \mathrm{~K}$ using liquid nitrogen. The equilibrium interval was $5 \mathrm{sec}$. The surface area was calculated using the B.E.T. method. Pore volume and area distributions based on the $\mathrm{BJH}$ calculation were evaluated by the B.E.T apparatus software (NOVA 1200-Quantachrome).

2.5. Scanning Electron Microscopy (SEM). Structural integrity and conformational changes, such as surface cavities in 
the support, set in by the lipase immobilizing procedure were observed by scanning electron microscopy (SEM) on Leica, LEO 440i.

2.6. Lipase Assay in Aqueous Solution. Hydrolytic activities of both free and immobilized lipase were measured with emulsified $p$-nitrophenyl palmitate ( $p$-NPP) according to Kordel et al. [20]. One volume of a $16.5 \mathrm{mM}$ solution of p-NPP in 2-propanol was mixed, just before, use with 9 volumes of $100 \mathrm{mM}$ phosphate buffer $\mathrm{pH} 7.0$ containing $0.4 \%(\mathrm{w} / \mathrm{v})$ Triton X-100 and $0.1 \%(\mathrm{w} / \mathrm{v})$ Arabic gum. Then, $2.7 \mathrm{~mL}$ of this mixture was pre-equilibrated at $37^{\circ} \mathrm{C}$ in a $1 \mathrm{~mL}$ cuvette of a UV-visible spectrophotometer (Varian UVCarry, Varian Corporation). The reaction was started by addition of $0.3 \mathrm{~mL}$ of enzyme solution (at an appropriate dilution in $100 \mathrm{mM}$ phosphate buffer $\mathrm{pH} 7.0$ ) or 0.1 to $0.2 \mathrm{mg}$ of immobilized lipase. The variation of the absorbance at $410 \mathrm{~nm}$ of the assay against a blank without enzyme was monitored for $5 \mathrm{~min}$. Reaction rate was calculated from the slope of the curve absorbance versus time by using a molar extinction coefficient of $13.10^{6} \mathrm{~cm}^{2} /$ mole for $p$-nitrophenol. This value was determined from the absorbance of standard solutions of $p$-NPP in the reaction mixture. One enzyme unit was the amount of enzyme liberating one $\mu$ mole of $p$ nitrophenol per minute in the above conditions.

2.7. Catalytic Properties of Free and Immobilized Lipase in Aqueous Medium. Free and immobilized hydrolytic activities were estimated with reaction mixtures containing $16.5 \mathrm{mM}$ solution of $p$-NPP and $50 \mathrm{mM}$ of sodium phosphate buffer at $\mathrm{pH}$ in the range from 6.0 to 8.5 at $37^{\circ} \mathrm{C}$. The effect of temperature on lipase activity was determined at temperatures from 37 to $60^{\circ} \mathrm{C}$ for the free and immobilized lipase. For thermal stability tests, both free and immobilized lipase preparations were incubated in sodium phosphate buffer $(\mathrm{pH} 8.0$ and 7.0, resp.) at different temperatures $\left(40\right.$ to $\left.60^{\circ} \mathrm{C}\right)$ for $1 \mathrm{~h}$. Samples were removed and assayed for residual activity as previously described (Lipase assay in aqueous solution), taking an unheated control to be $100 \%$ active. The influence of substrate concentration on hydrolytic activities was also analyzed in $p$-NPP solutions at concentrations varying from 100 to $1000 \mu \mathrm{M}$ at $37^{\circ} \mathrm{C}$. Values for $K_{m}$ and $V_{\max }$ were calculated using the computational program Enzyme fitter version 1.05 published by Elsevier-Biosoft, 1987.

\subsection{Stability Tests}

2.8.1. Thermal Analysis. Thermal gravimetric analysis was performed in a Shimadzu thermogravimetric instrument, TGA-50 model. Samples weighting $10 \mathrm{mg}$ were examined at heating rates of $10^{\circ} \mathrm{C} \cdot \mathrm{min}^{-1}$ in a dry nitrogen flux from 30 to $600^{\circ} \mathrm{C}$.

2.8.2. Stability Tests. For thermal stability tests, both free and immobilized lipase preparations were incubated in $100 \mathrm{mM}$ phosphate buffer ( $\mathrm{pH} 8.0$ and 7.0, resp.) at different temperatures $\left(40\right.$ to $\left.55^{\circ} \mathrm{C}\right)$ for $1 \mathrm{~h}$. Samples were removed and assayed for residual activity as previously described (lipase assay in aqueous solution), taking an unheated control to be $100 \%$ active. Inactivation constants $\left(k_{d}\right)$ and half-life $\left(t_{1 / 2}\right)$ for both free and immobilized lipases were calculated according to (1) and (2), as shown below:

$$
\begin{gathered}
\ln A_{t}=\ln A_{0}-k_{d} \cdot t, \\
t_{1 / 2}=\frac{\ln 0.5}{-k_{d}},
\end{gathered}
$$

where $A_{0}$ is the initial activity, and $A_{t}$ is the activity after heat treatment for $t$ minutes.

The operational stability of the immobilized preparation was assayed in synthesis of butyl butyrate in successive batch runs. Reaction systems consisted of heptane $(20 \mathrm{~mL}), n$ butanol $(100 \mathrm{mM})$, butyric acid $(100 \mathrm{mM})$ and immobilized lipase in niobium oxide $(0.5 \mathrm{~g}, \mathrm{~d} . \mathrm{wt})$. The mixture was incubated at $37^{\circ} \mathrm{C}$ for $24 \mathrm{~h}$ with continuous agitation at $150 \mathrm{rpm}$. At the end of each batch, the immobilized lipase was removed from the reaction medium and washed with hexane to remove any substrate or product retained in the matrix. Then, the immobilized lipase was introduced into a fresh medium. Reactions were monitored by measuring reactants and product concentrations by gas chromatography using a $6 \mathrm{ft} 5 \%$ DEGS on Chromosorb WHP, 80/10 mesh column (Hewlett Packard, Palo Alto, CA, USA) and hexanol was used as an internal standard. Water concentrations in liquid and solid phases were measured by Karl Fischer (Mettler DL 18). Activities were estimated at the end of each cycle and expressed as $\mu \mathrm{mol} \cdot \mathrm{min}^{-1} \cdot \mathrm{mg}^{-1}$ of catalyst. The biocatalyst half-life $\left(t_{1 / 2}\right)$ was determined by applying the inverted linear decay model [21].

2.9. General Procedure for Biodiesel Synthesis. The reactions were performed in closed reactors with capacity of $25 \mathrm{~mL}$, coupled with condensers, containing $12 \mathrm{~g}$ of substrate consisting of babassu oil and short chain alcohol (ethanol, propanol or butanol), without addition of solvents, at molar ratio oil to alcohol $(1: 10)$. The mixtures were incubated with $C$. rugosa immobilized in niobium oxide at proportions of $20 \%$ wt. in relation to the total weight of reactant involved in the reaction media. The experiments were carried out at temperature range from 40 to $50^{\circ} \mathrm{C}$, depending on the reaction system, according to what was previously established in [6]. Reactions were performed for a maximum period of $96 \mathrm{~h}$ under constant magnetic agitation of $150 \mathrm{rpm}$. For the time course studies, an aliquot of reaction medium was taken at various time intervals and diluted in $n$-heptane for GC-analysis.

2.10. GC Analysis. Samples prepared as described above were analyzed by injecting $1 \mu \mathrm{L}$ of heptane solution and internal standard into a GC (Varian Model 3800), equipped with a $6 \mathrm{ft} 5 \%$ DEGS on Chromosorb WHP, 80/10 mesh column (Hewlett Packard, Palo Alto, CA, USA) following conditions previously established in [6]. All samples were measured in triplicate. Theoretical ester concentrations were calculated by taking into consideration the babassu oil fatty acid composition and its initial weight mass in the reaction medium $[6,7]$. 


\section{Results and Discussion}

3.1. Morphological Biocatalyst Characterization. The morphology, distribution, and size of the particles for pure, silanized, and activated niobium oxide and immobilized derivative were studied by micrographics obtained in scanning electronic microscope as presented in Figures 1(a), 1(b), $1(\mathrm{c})$, and 1(d). The method of B.E.T was also used as tool for evaluating the specific surface area, mean pore diameter, and pore volume average of these samples.

Figure 1(a) shows that the pure niobium oxide is formed by particles having irregular size and surface showing different arrangements with a specific surface area of $42.15 \mathrm{~m}^{2} / \mathrm{g}$ and pore volume of $0.029 \mathrm{~cm}^{3} / \mathrm{g}$. After the support silanization with $\gamma$-APTS (Figure 1(b)) the particles became more compacted, not showing any more empty spaces, a situation that also was confirmed by the specific surface area and pore volume values. With the incorporation of the silane group in the support surface and inside the pores, the specific surface area was reduced to $31.89 \mathrm{~m}^{2} / \mathrm{g}$ and pore volume to $0.024 \mathrm{~cm}^{3} / \mathrm{g}$. Comparing the micrographs for niobium oxide silanized (Figure 1(b)) and activated with glutaraldehyde (Figure 1(c)), slight visual changes in the particle size and form were observed as further confirmed by the specific surface area and pore volume values, respectively, $33.57 \mathrm{~m}^{2} / \mathrm{g}$ and $0.027 \mathrm{~cm}^{3} / \mathrm{g}$. The treatment with silane agent open the porous matrix and activation with glutaraldehyde reduced the surface area and pore volume due to the cross-linking reaction on the support surface. For the immobilized lipase on niobium oxide (Figure $1(\mathrm{~d})$ ), the micrograph shows that the support particles were fully covered by the enzyme and individual support particles cannot be any more visualized, which again was confirmed by the reduction on the specific surface area $\left(10.08 \mathrm{~m}^{2} / \mathrm{g}\right)$ and the pore volume $\left(0.011 \mathrm{~cm}^{3} / \mathrm{g}\right)$.

In the immobilization procedure, another fundamental parameter is the support pore size, which should be sufficiently large to allow the enzyme accommodation. The niobium oxide silanized and activated with GA showed a pore volume of $0.027 \mathrm{~cm}^{3} / \mathrm{g}$ and the Candida rugosa lipase presents a molecular volume of $6.93 \times 10^{-20} \mathrm{~cm}^{3}(5 \times 4.2 \times$ $3.3 \mathrm{~nm}^{3}$ ) [22], proving that the enzyme did not suffer any barrier to access the pore of the support.

\subsection{Biochemical and Kinetic Properties of the Immobilized} Lipase on Niobium Oxide. The $\mathrm{pH}$ and temperature profiles of hydrolytic activities are shown in Figures 2 and 3, respectively. The $\mathrm{pH}$ optimum shifted $1.0 \mathrm{pH}$ point from about 8.0 for the free enzyme, to about 7.0 for the immobilized lipase (Figure 2). However, this shift depended on the method of immobilization as well as the structure of the matrix, mainly the support charge surface. In relation to the support niobium oxide due to its positive charged, the optimal $\mathrm{pH}$ for immobilized lipase shifted to the acidic side. In the present work, however, care was taken to avoid the electrostatic potential within the immobilized lipase by carrying out the niobium oxide activation step in buffering $\mathrm{pH}$ solution (glutaraldehyde in phosphate buffer, $100 \mathrm{mM}$ and $\mathrm{pH}$ 8.0), as described in Section 2. This was a necessary step since the charge groups on the support surfaces may induce acid or
TABLE 1: Biochemical and kinetics properties of the free and immobilized lipase.

\begin{tabular}{lcc}
\hline Parameter & Free lipase & Immobilized lipase \\
\hline Optimum $\mathrm{pH}$ & 8.0 & 7.0 \\
Optimum temperature $\left({ }^{\circ} \mathrm{C}\right)$ & 37 & 55 \\
$K_{m}(\mu \mathrm{M})$ & 0.17 & 0.17 \\
$V_{\max }(\mathrm{U} / \mathrm{mg})$ & 1928.66 & 89.23 \\
\hline
\end{tabular}

base catalyzed acyl migration that should be avoided during lipase-catalyzed process [23].

The optimum temperature for the immobilized enzyme $\left(55^{\circ} \mathrm{C}\right)$ was $18^{\circ} \mathrm{C}$ higher than for the soluble enzyme $\left(37^{\circ} \mathrm{C}\right)$, as shown in Figure 3. The increase in the optimum temperature of the immobilized lipase may be explained by the change of the conformational integrity of the enzyme structure upon covalent attachment to the support. The increase in the optimum temperature of the immobilized lipase is important for a possible industrial application because it allows to reduce microbial contamination and viscosity reduction of oil and greases, favoring high yield process, such as biodiesel production from vegetable oils.

The influence of substrate concentration on hydrolytic activities was also analyzed for free and immobilized lipase in $p$-NPP solutions varying from 100 to $1000 \mu \mathrm{M}$ (Figures 4(a) and 4(b)) to determine the Michaelis-Menten constant $\left(K_{m}\right)$ as the concentration of substrate at which half of the maximum reaction rate $\left(V_{\max }\right)$ is reached. Plotting activity versus substrate concentration indicated that both lipases obey the Michaelis-Menten equation, indicating that in the range studied, no inhibition by reaction product was detected. The values obtained for $K_{m}$ were 0.17 and $0.17 \mu \mathrm{M}$ for the free and immobilized lipase, respectively, indicating similar substrate affinity to the active site of the free and immobilized lipase. The maximum reaction rate $\left(V_{\max }\right)$ for $p$-NPP hydrolysis with the free lipase was $1928.66 \mu \mathrm{mol} \cdot \mathrm{mg}^{-1} \cdot \mathrm{min}^{-1}$ and $89.23 \mu \mathrm{mol} \cdot \mathrm{mg}^{-1} \cdot \mathrm{min}^{-1}$ for the immobilized lipase. This decrease on the maximum reaction rate was either due to the conformational changes of the enzyme resulting in a lower possibility of forming a substrate-enzyme complex, or a less access of the substrate to the active sites of the immobilized enzyme caused by the increased diffusion limitation $[23,24]$. In Table 1 the biochemical and kinetics parameters of the both free and immobilized lipase are summarized.

\subsection{Stability Tests}

3.3.1. Thermal Stability. The thermal stability of enzymes is one of the important criteria for long-term and commercial application. The activity of immobilized enzyme is known to be more resistant against heat than native state. Thermal gravimetric analysis (TGA) provides an important tool for thermal stability studies of macromolecules $[25,26]$. This technique enables to determine the temperature range at which a heated sample undergoes a major conformational change by means of monitoring the thermal weight loss profile. In the case of free lipase and immobilized lipase 


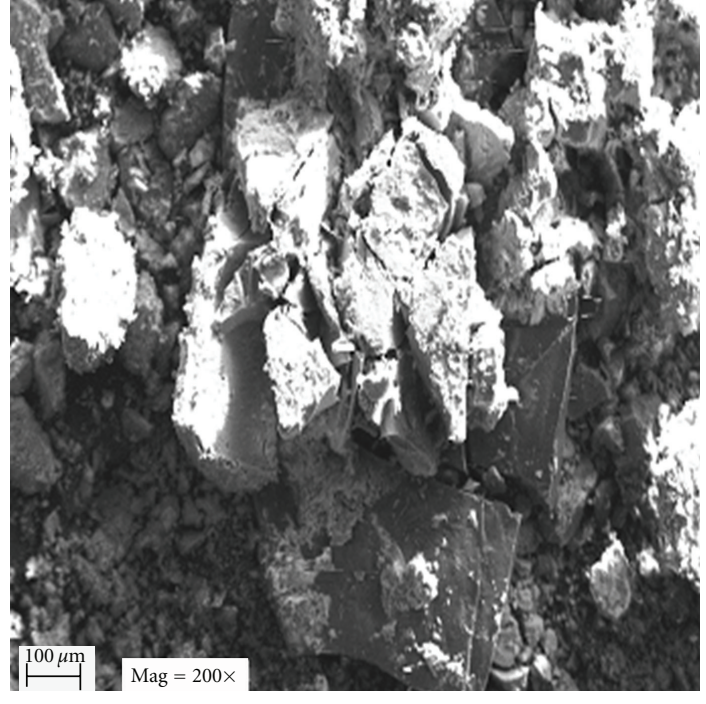

(a)

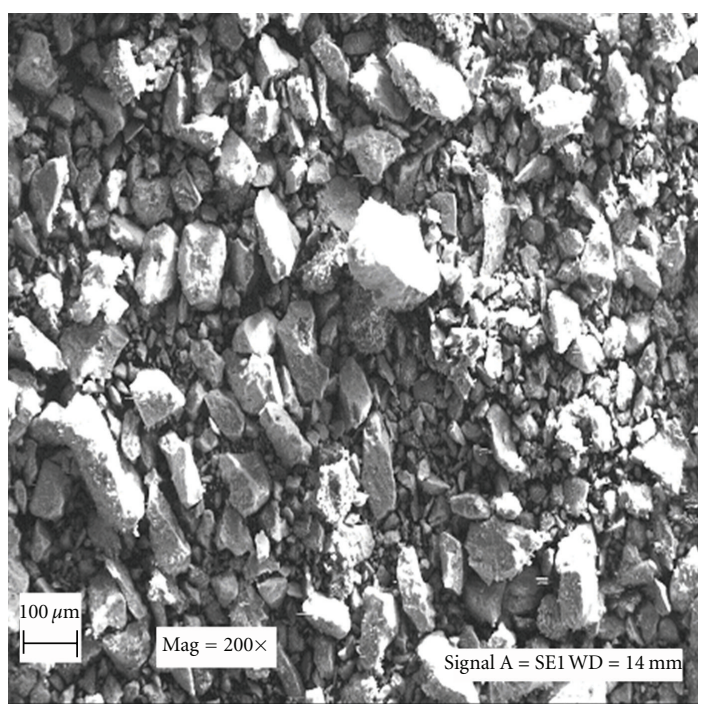

(c)

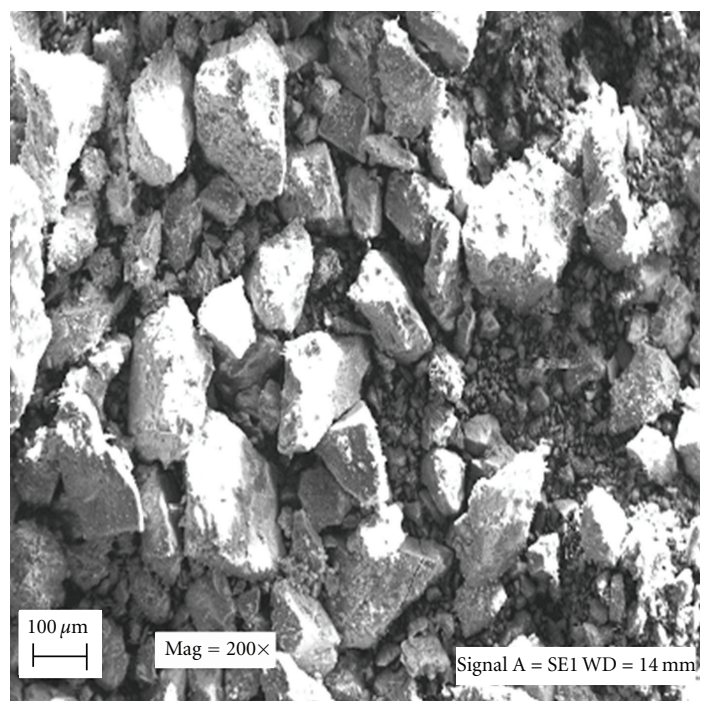

(b)

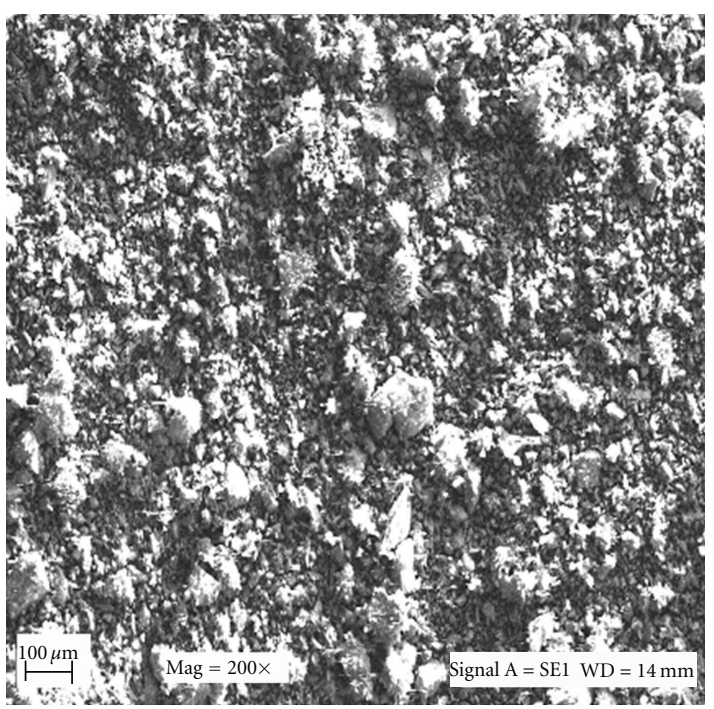

(d)

FIGURE 1: Scanning electron micrographs (SEM): (a) pure niobium oxide; (b) silanized niobium oxide; (c) silanized and activated niobium oxide; (d) immobilized CRL on niobium oxide.

derivative such temperature range can be related to the protein unfolding and thus to the enzyme inactivation. Thermal degradation temperatures were determined for free lipase, hydrous niobium oxide, and the resulting immobilized lipase derivative. Thermal weight loss results are showed in Table 2.

Free lipase was characterized by two weight loss peaks. In the first one, at temperature range from 30 to $180^{\circ} \mathrm{C}$, distinguished by a low weight loss (4.3\%) due to the dehydration of the interstitial water containing in the free lipase sample. From 180 to $600^{\circ} \mathrm{C}$, continuous weight loss was observed indicating a complete decomposition of the organic structure of lipase.

The thermogravimetric analysis for the niobium oxide indicated a large weight loss $(10.5 \%)$ at temperature lower than $200^{\circ} \mathrm{C}$ and a small one $(4.9 \%)$ from 200 to $400^{\circ} \mathrm{C}$. The former weight loss was due to the elimination of the free water and the latter to the water that it held in the support pores [26]. For the lipase immobilized on silanized and activated niobium oxide showed weight loss in two steps. The first was characterized by a weight loss (13.6\%) at 30 to $200^{\circ} \mathrm{C}$ due to the elimination of hydration water and the second step was characterized by $5 \%$ weight loss at 200 to $400^{\circ} \mathrm{C}$ corresponding to water loss that is held in the pores. The results indicated that upon immobilization, the profile curves for lipase derivative shifted towards higher temperatures suggesting that a strong interaction between enzyme and the support occurred which enhanced the conformation stability of the native form.

According to Table 3, free $\mathrm{CRL}$ at $55^{\circ} \mathrm{C}$ shows a halflife of $0.38 \mathrm{~h}$, maintaining only $20 \%$ of its original activity after $1 \mathrm{~h}$, whereas the half-life of the immobilized lipase at this temperature was $0.82 \mathrm{~h}$. The conformational flexibility 


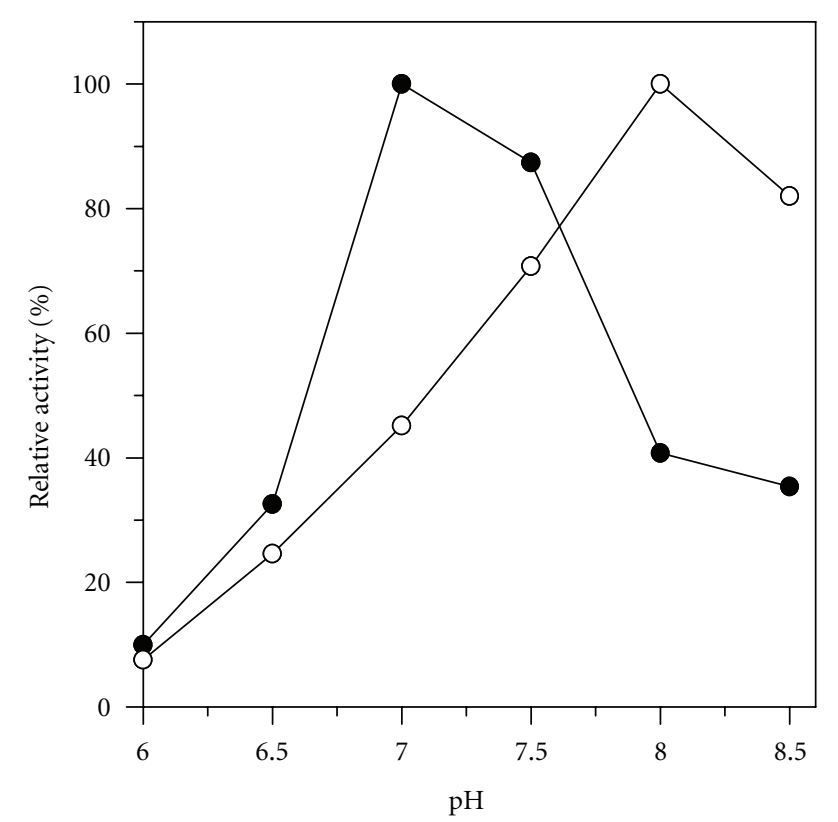

FIGURE 2: Effect of reaction $\mathrm{pH}$ on hydrolytic activities of lipase preparations. Enzymes were assayed with $p$-NPP as substrate at $37^{\circ} \mathrm{C}$, $(\circ)$ free lipase, $(\bullet)$ niobium oxide-lipase. Starting activities (free lipase: 1553 units $\cdot \mathrm{mg}^{-1}$; niobium oxide-lipase: 143 units $\cdot \mathrm{mg}^{-1}$ ) were taken as $100 \%$.

of the enzyme was reduced after immobilization $[23,24$, $27,28]$. Immobilization of the lipase on niobium oxide led to an increase of enzyme rigidity, which protected it from unfolding. Thus the immobilized enzyme showed higher thermal stability than free enzyme, twice fold more stable than free lipase, similar stabilization factor (ratio between half-life of the immobilized and free lipase) observed at $50^{\circ} \mathrm{C}$.

3.3.2. Storage Stability. To complete the characterization of the immobilized lipase, the hydrolytic activity was measured as a function of long-term storage time at refrigerated temperature $\left(4^{\circ} \mathrm{C}\right)$, and after 60 days the activity decreased by $80 \%$. Results from literature, show that immobilized lipase from porcine pancreas (PPL) in chitosan stored in water and without any medium (dry), after four and ten days was verified total reduction of the hydrolytic activity of the immobilized derivates, respectively [29].

3.3.3. Operational Stability. Considering that operational stability is a parameter of fundamental importance in developing processes with immobilized enzymes, complementary tests were performed to determine the biocatalyst half-life time for immobilized lipase in organic (ester synthesis) medium (Figure 5). For the esterification reaction of butanol with butyric acid $\left(24 \mathrm{~h}-37^{\circ} \mathrm{C}\right)$, a slow decrease in the esterification activity was verified $(25 \%)$ after ten recycles $(240 \mathrm{~h})$, which corresponds to a half-life $\left(t_{1 / 2}\right)$ of $406 \mathrm{~h}$.

3.4. Application of the Prepared Derivative for Biodiesel Synthesis. Transesterification reactions were performed using babassu oil and short-chain alcohol such as ethanol,

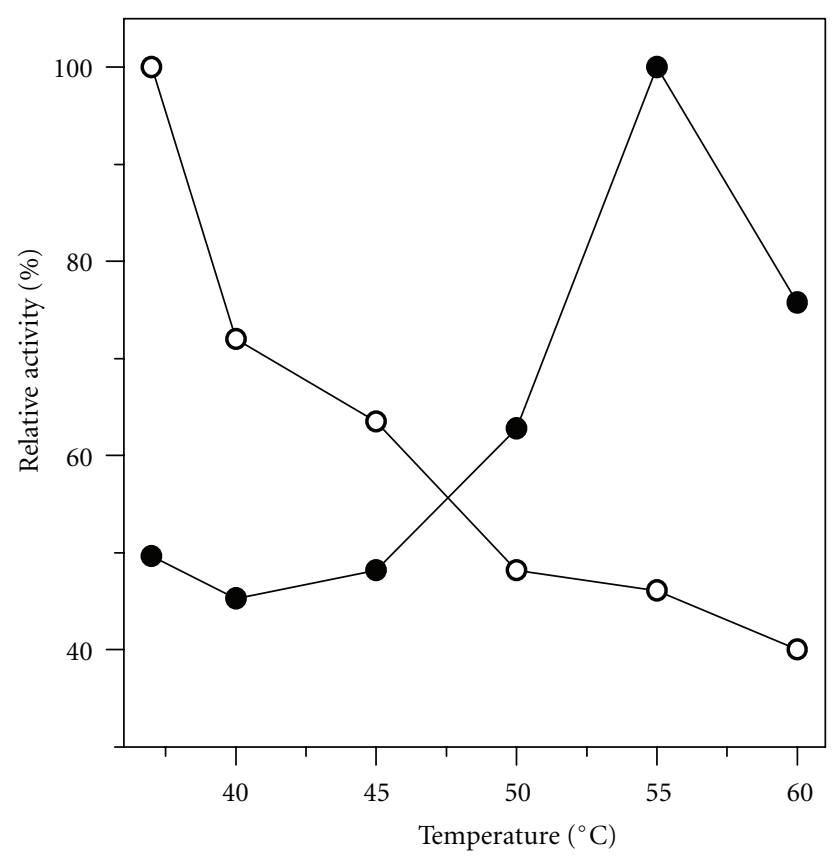

FIGURE 3: Effect of reaction temperature on hydrolytic activities of lipase preparations. Enzymes were assayed with $p$-NPP as substrate at $\mathrm{pH} 7.0,(\circ)$ free lipase, $(\bullet)$ niobium oxide-lipase. Starting activities (free lipase: 1868 units $\cdot \mathrm{mg}^{-1}$; niobium oxidelipase: 271 units $\cdot \mathrm{mg}^{-1}$ ) were taken as $100 \%$.

TABLE 2: Thermogravimetric analysis for support, free lipase, and immobilized derivative.

\begin{tabular}{lccc}
\hline Material & $\begin{array}{c}\text { Temperature } \\
\text { range }\left({ }^{\circ} \mathrm{C}\right)\end{array}$ & $\begin{array}{c}\text { Thermal degradation } \\
\text { temperature* }\left({ }^{\circ} \mathrm{C}\right)\end{array}$ & $\begin{array}{c}\text { Weight } \\
\text { loss }(\%)\end{array}$ \\
\hline Pure support & $30-200$ & 53 & 10.5 \\
& $200-400$ & 52 & 4.9 \\
Free lipase & $30-180$ & 54 & 4.3 \\
Immobilized & $30-200$ & & 13.6 \\
lipase & $200-400$ & 5.0 \\
\hline
\end{tabular}

* Temperature at which a heated sample undergoes a major weight loss.

propanol, and butanol catalyzed by Candida rugosa lipase on immobilized niobium oxide in solvent-free system. The longchain fatty acid alkyl esters (FAAEs) produced (biodiesel) can be used as substitute to the conventional diesel fuel without any modification in engine design $[3,4]$. Figure 6 shows the progress of the enzymatic reaction for each system in terms of monoalkyl esters formation.

According to the results, Candida rugosa lipase was strongly inactivated when ethanol was used as acyl acceptor (transesterification yield $=4.36 \%$ ), a result which is in agreement with those related in the literature [30, 31]. Conversion of babassu oil into fatty acid alkyl esters (FAAEs) was also affected by propanol reaching a yield lower than $40 \%$. The lower performance into fatty acid alkyl esters formation when ethanol and propanol were used as acyl acceptors can be attributed to the high polarity of these alcohols, which leads to an unfavored partition of water between enzyme and support, thus stripping essential water 


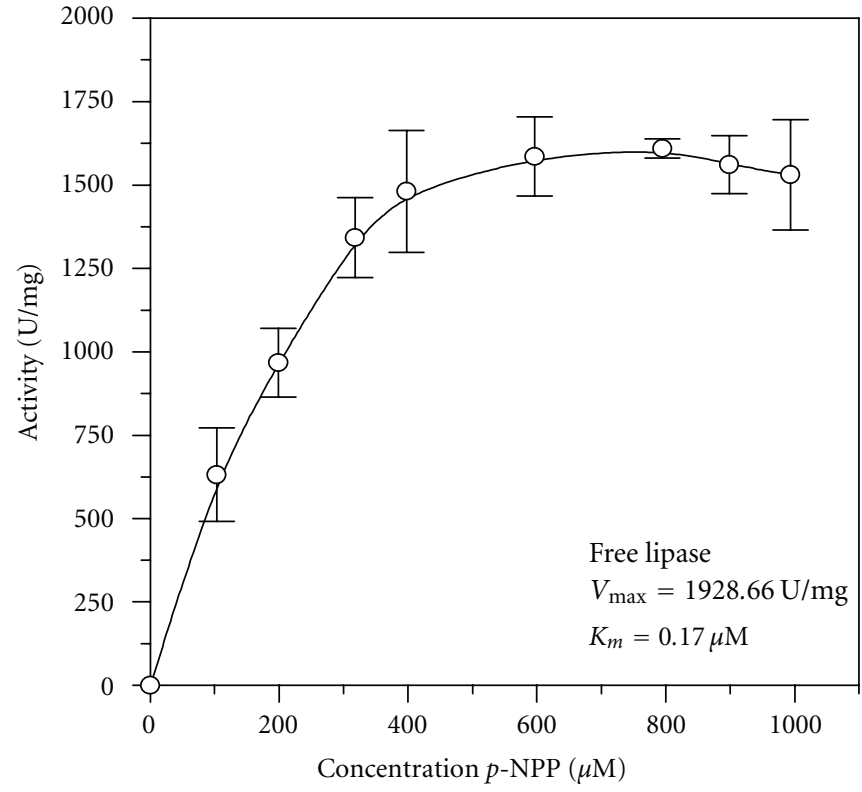

(a)

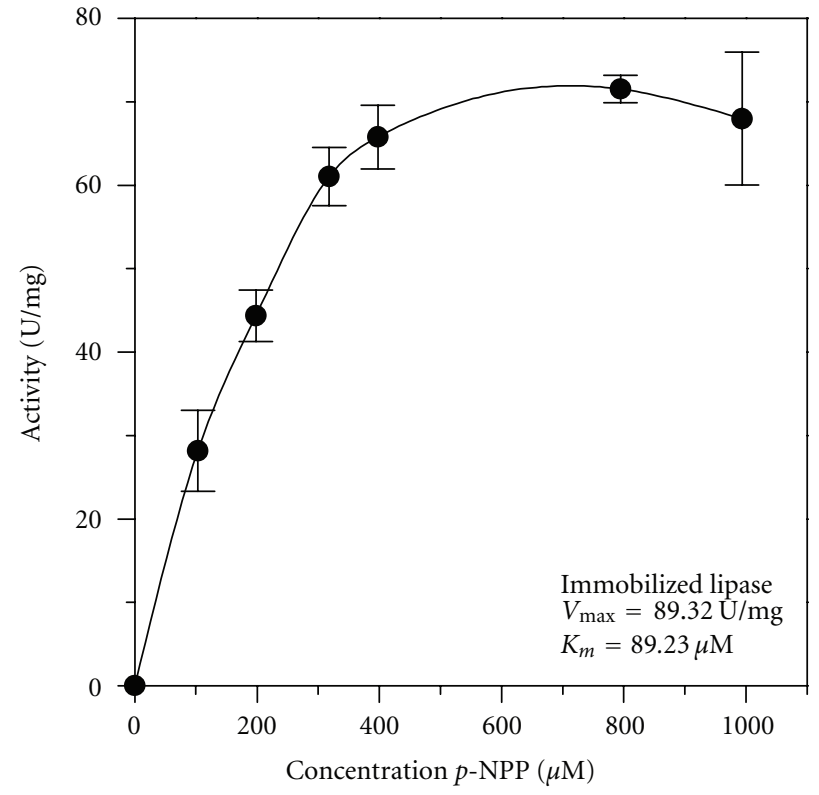

(b)

FIgURE 4: Hydrolytic activities for free lipase (a) and niobium oxide lipase (b) as a function of $p$-NPP concentration at $\mathrm{pH} 7.0$ and $37^{\circ} \mathrm{C}$.

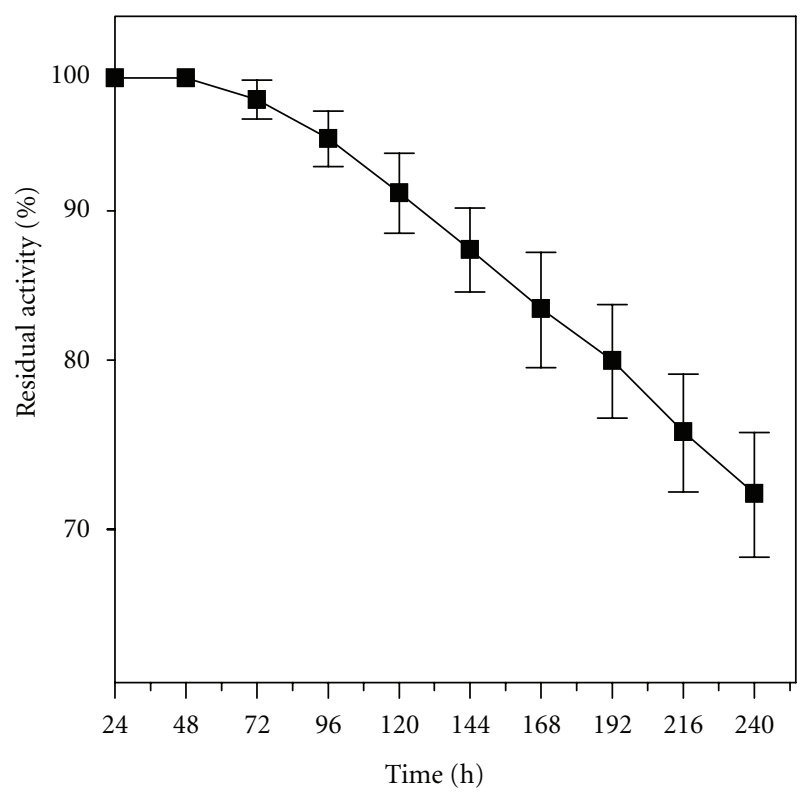

FIGURE 5: Batch operational stability tests for lipase immobilized in niobium oxide lipase in organic media. Initial activity $\left(54.46 \mu \mathrm{mol} \cdot \mathrm{g}^{-1} \cdot \mathrm{min}^{-1}\right)$ was defined as $100 \%$.

from enzyme molecules and reducing the CRL activity. Enzymatic activity and stability are highly dependent on the degree of hydration of the enzyme and a minimum amount of water is necessary for the protein to maintain its optimal conformation [30, 31].

Therefore, in the conversion of babassu oil into alkyl esters butanol gave the highest conversion (79.35\%), showing a better activity of the Candida rugosa lipase with increasing alcohol chain lengths due to the lowest polarity of the butanol in relation to the ethanol and propanol. Similar results were reported by Cambon et al. [31] in the transesterification of sunflower oil catalyzed by vegetal lipase.

3.5. Economical Evaluation for the Manufacture of the Immobilized Lipase on Niobium Oxide. The use of enzymes as industrial catalysts for replacing the conventional chemical processes is limited mainly by the high biocatalyst and its low operational stability. The immobilization in appropriate supports can overcome such limitation since the initial investment in raw material (enzyme, support, and reagents) is expected to be rewarded by the high activity and stability of the resulted immobilized derivative $[13,16]$.

To estimate the overall cost for preparing the immobilized lipase on niobium oxide, it was taken into consideration a batch starting from $100 \mathrm{~g}$ of pure niobium oxide and the reagent costs, including the free lipase as stated in catalog prices directed available from the manufactures. The involved cost for the immobilizing procedure to obtain immobilized derivative on controlled pore silica (US\$ 67.0/g) was used for comparative purpose. The cost of Candida rugosa lipase immobilized on niobium oxide was estimated to be 1.06 US\$/g immobilized system, corresponding to value 64 times lower than one obtained by the immobilization derivative of that same lipase on controlled pore silica (US\$ 68.0/g immobilized system). Considering that the lipase immobilized on niobium oxide showed similar values for thermal and operational stabilities to that one obtained for the lipase immobilized on commercial inorganic matrix, as controlled pore silica [32], it can be inferred that the proposed matrix according to the description given in this work can be replaced with technical and economical advantages of commercial inorganic matrixes, as controlled 


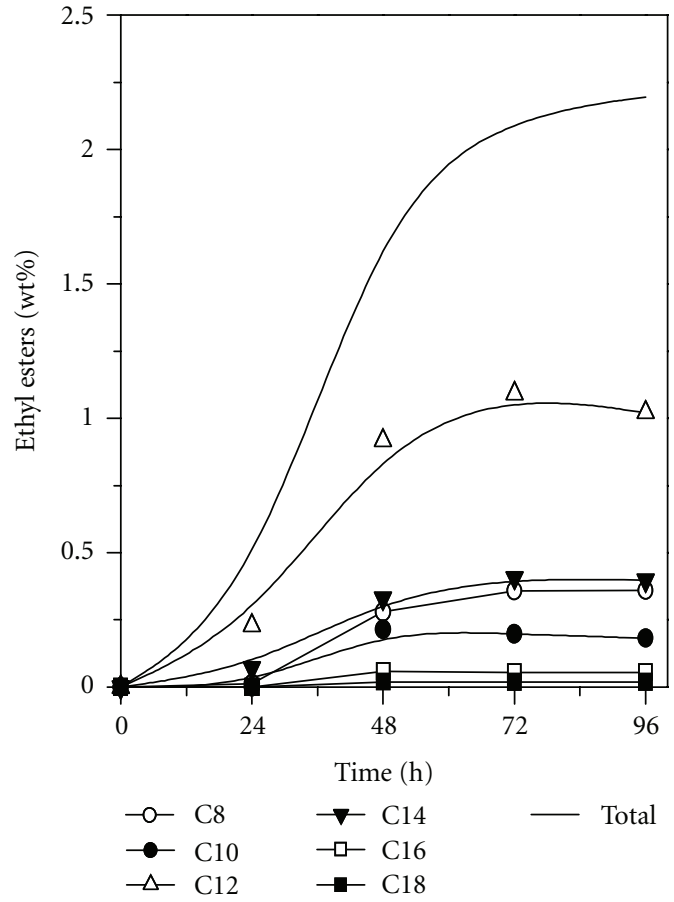

(a)

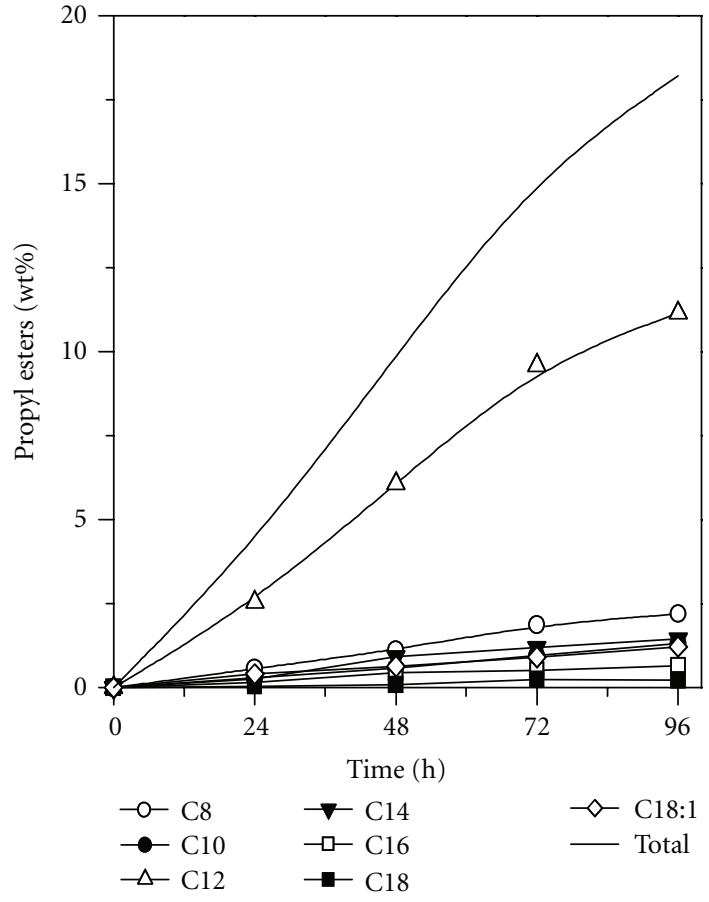

(b)

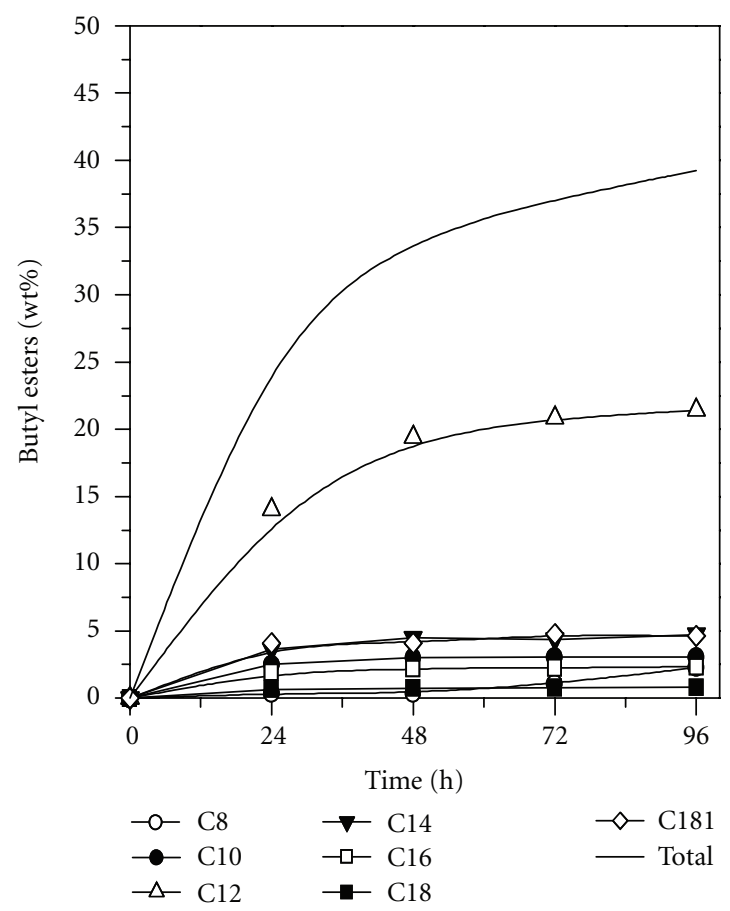

(c)

Figure 6: Profile for alkyl esters formation in the transesterification reaction of the babassu oil with ethanol (a), propanol (b), and butanol (c) catalyzed by CRL immobilized on niobium oxide as biocatalyst.

pore silica. For a better evaluation of the properties obtained by the lipase immobilized on niobium oxide, comparative data described in the literature for experimental preparations of Candida rugosa immobilized on inorganic matrixes, as zirconium phosphate (ZrP), controlled pore silica (CPS) and silica-gel obtained by the sol-gel technique using MTMS as precursor $[24,32,33]$ is given in Table 4.

In terms of activity recovery and operational stability, the matrix used in the present work shows comparable performance with other inorganic matrixes, indicating that 
TABLE 3: Half-life $\left(t_{1 / 2}\right)$ and rate of denaturation $\left(k_{d}\right)$ for the free and immobilized lipases.

\begin{tabular}{lcccc}
\hline \multirow{2}{*}{ Temperature $\left({ }^{\circ} \mathrm{C}\right)$} & \multicolumn{2}{c}{ Rate of denaturation $\left(k_{d}\right)\left(\mathrm{h}^{-1}\right)$} & \multicolumn{2}{c}{ Half-life $\left(t_{1 / 2}\right)=-\ln (1 / 2) / k_{d}(\mathrm{~h})$} \\
& Free lipase & Immobilized lipase & Free lipase & Immobilized lipase \\
\hline 40 & 0.23 & 0.22 & 3.03 & 3.15 \\
50 & 1.15 & 0.52 & 0.60 & 1.36 \\
55 & 1.81 & 0.84 & 0.38 & 0.82 \\
\hline
\end{tabular}

TABle 4: Comparison of the catalytic properties of the Candida rugosa lipase immobilized in different inorganic supports.

\begin{tabular}{|c|c|c|c|c|}
\hline \multirow{2}{*}{ Property } & \multicolumn{4}{|c|}{ Support } \\
\hline & $\mathrm{CPS}^{\mathrm{a}}$ & Silica ${ }^{\mathrm{b}}$ (sol-gel) & $\mathrm{ZrP}^{\mathrm{c}}$ & $\mathrm{Nb}_{2} \mathrm{O}_{5}$ \\
\hline Activity recovered (\%) & 48 & 1.34 & 60 & $47.5^{*}$ \\
\hline Hydrolytic activity (U/mg) & 119 & 4.98 & 163 & $124^{*}$ \\
\hline Esterification Activity $(\mu \mathrm{M} / \mathrm{g} \cdot \min )$ & 154 & 136 & 103 & $120^{*}$ \\
\hline Operational stability in organic medium $\left(t_{1 / 2}\right.$ at $\left.37^{\circ} \mathrm{C}, \mathrm{h}\right)$ & 417 & 132 & 412 & 406 \\
\hline References & {$[32]$} & [33] & [24] & This work \\
\hline
\end{tabular}

${ }^{\mathrm{a}}$ CPS: Controlled pore silica.

bencapsulated lipase in hydrophobic matrix obtained by sol-gel process using as precursor MTMS (methyltrimethoxysilane).

'ZrP: zirconium phosphate.

* results previously reported [16].

niobium oxide can be used as an alternative to commercial matrices, such as controlled pore silica.

\section{Conclusion}

The immobilized derivative obtained under the conditions previously established was fully characterized with respect to its morphological properties: particle size, surface specific area, and pore size distribution (B.E.T. method) and yield of grafting (TGA). Structural integrity and conformational changes, such as surface cavities in the support, set by the lipase procedure were observed by scanning electron microscopy (SEM). The catalytic performance of the immobilized derivative was also determined in aqueous (hydrolysis of ester) and in nonaqueous media (synthesis of ester and modification of vegetable oil). In aqueous media, a comparative study between free and immobilized lipase was made in terms of $\mathrm{pH}$, temperature, thermal stability, and kinetics parameters using $p$-phenyl palmitate as substrate. Upon immobilization the lipase shifted optima conditions for lower $\mathrm{pH}(7.00)$ and higher temperature $\left(55^{\circ} \mathrm{C}\right)$ values when compared with the lipase in its free form $(\mathrm{pH} 8.0$ and temperature of $37^{\circ} \mathrm{C}$ ). Thermal stability tests revealed that the immobilized derivative showed higher thermal stability than the free lipase. The influence of the substrate concentration on the reaction rate showed good adjustment of Michaelis Menten model, with an estimation of the same $K_{m}$ values for both free and immobilized enzymes $(0.17 \mu \mathrm{M})$ and $V_{\max }$ values of $1928.66 \mathrm{U} / \mathrm{mg}$ for free and $89.23 \mathrm{U} / \mathrm{mg}$ for immobilized lipase.

In nonaqueous media, the catalytic potential of the immobilized derivative was verified in the esterification reaction of butanol with butyric acid (operational stability) and transesterification reaction of babassu oil with short chain alcohols. In the operational tests, the immobilized derivative was used successively under batch reactions $\left(24 \mathrm{~h} / 37^{\circ} \mathrm{C}\right)$ maintaining up to $70 \%$ of the initial activity up to $240 \mathrm{~h}$, revealing a biocatalyst half-life of $406 \mathrm{~h}$. CRL was inhibited when ethanol and propanol were used as acyl donors in the transesterification of babassu oil into biodiesel. Therefore, the immobilized lipase was shown to be only effective for the transesterification with butanol, reaching satisfactory concentrations of butyl esters.

\section{Acknowledgments}

The authors acknowledge the financial assistance from CNPq, Fundação de Apoio à Pesquisa do Estado de São Paulo (FAPESP) and Coordenação de Aperfeiçoamento de Pessoal de Nível Superior (CAPES).

\section{References}

[1] M. P. Dorado, E. Ballesteros, J. M. Arnal, J. Gómez, and F. J. López, "Exhaust emissions from a Diesel engine fueled with transesterified waste olive oil," Fuel, vol. 82, no. 11, pp. 13111315, 2003.

[2] C. D. Rakopoulos, "Comparative performance and emission studies when using olive oil as a fuel supplement in DI and IDI diesel engines," Renewable Energy, vol. 2, no. 3, pp. 327331, 1992.

[3] L. C. Meher, D. V. Sagar, and S. N. Naik, "Technical aspects of biodiesel production by transesterification-a review," Renewable and Sustainable Energy Reviews, vol. 10, no. 3, pp. 248-268, 2006.

[4] S. V. Ranganathan, S. L. Narasimhan, and K. Muthukumar, "An overview of enzymatic production of biodiesel," Bioresource Technology, vol. 99, no. 10, pp. 3975-3981, 2008.

[5] A. B. R. Moreira, V. H. Perez, G. M. Zanin, and H. F. de Castro, "Biodiesel synthesis by enzymatic transesterification of palm oil with ethanol using lipases from several sources 
immobilized on silica-PVA composite," Energy and Fuels, vol. 21, no. 6, pp. 3689-3694, 2007.

[6] D. Urioste, M. B. A. Castro, F. C. Biaggio, and H. F. de Castro, "Síntese de padrões cromatográficos e estabelecimento de método para dosagem da composição de ésteres de ácidos graxos presentes no biodiesel a partir do óleo de babaçu," Quimica Nova, vol. 31, no. 2, pp. 407-412, 2008.

[7] L. Freitas, P. C. M. Da Rós, J. C. Santos, and H. F. de Castro, "An integrated approach to produce biodiesel and monoglycerides by enzymatic interestification of babassu oil (Orbinya sp)," Process Biochemistry, vol. 44, no. 10, pp. 1068-1074, 2009.

[8] R. Sharma, Y. Chisti, and U. C. Banerjee, "Production, purification, characterization, and applications of lipases," Biotechnology Advances, vol. 19, no. 8, pp. 627-662, 2001.

[9] F. Hasan, A. A. Shah, and A. Hameed, "Industrial applications of microbial lipases," Enzyme and Microbial Technology, vol. 39, no. 2, pp. 235-251, 2006.

[10] S. Benjamin and A. Pandey, "Candida rugosa lipases: molecular biology and versatility in biotechnology," Yeast, vol. 14, no. 12, pp. 1069-1087, 1998.

[11] G. Fernández-Lorente, R. Fernández-Lafuente, J. M. Palomo et al., "Biocatalyst engineering exerts a dramatic effect on selectivity of hydrolysis catalyzed by immobilized lipases in aqueous medium," Journal of Molecular Catalysis B, vol. 11, no. 4-6, pp. 649-656, 2001.

[12] R. Verger, "Interfacial activation' of lipases: facts and artifacts," Trends in Biotechnology, vol. 15, no. 1, pp. 32-38, 1997.

[13] G. Fernández-Lorente, Z. Cabrera, C. Godoy, R. FernándezLafuente, J. M. Palomo, and J. M. Guisán, "Interfacially activated lipases against hydrophobic supports: effect of the support nature on the biocatalytic properties," Process Biochemistry, vol. 43, no. 10, pp. 1061-1067, 2008.

[14] L. Sarda and P. Desnuelle, "Action de la lipase pancreatique sur les esteres en emulsion," Biochimica et Biophysica Acta, vol. 30, pp. 513-521, 1958.

[15] M. J. S. Serafim, Obtenção e caracterização do hidróxido de nióbio $V$ como trocador iônico, MSc Dissertation, Escola de Engenharia de Lorena-EEL-USP, São Paulo, Brazil, 1994.

[16] M. Miranda, M. L. C. P. da Silva, and H. F. de Castro, "Optimised immobilisation of microbial lipase on hydrous niobium oxide," Journal of Chemical Technology and Biotechnology, vol. 81, no. 4, pp. 566-572, 2006.

[17] H. Motoo, JP Patent 62192308, 1987.

[18] O. Kuurutan, JP Patent 4230308, 1992.

[19] M. Reinhard, S. Kurt, K. Anke, H. Detlef, and I. Iduna, US Patent 6045779, 2000.

[20] M. Kordel, B. Hofmann, D. Schomburg, and R. D. Schmid, "Extracellular lipase of Pseudomonas sp. strain ATCC 21808: purification, characterization, crystallization, and preliminary X-ray diffraction data," Journal of Bacteriology, vol. 173, no. 15, pp. 4836-4841, 1991.

[21] L. P. Fonseca, J. P. Cardoso, and J. M. S. Cabral, "Immobilization studies of an industrial penicillin acylase preparation on a silica carrier," Journal of Chemical Technology and Biotechnology, vol. 58, no. 1, pp. 27-37, 1993.

[22] S. Gao, Y. Wang, X. Diao, G. Luo, and Y. Dai, "Effect of pore diameter and cross-linking method on the immobilization efficiency of Candida rugosa lipase in SBA-15," Bioresource Technology, vol. 101, no. 11, pp. 3830-3837, 2010.

[23] F. M. Gomes, E. B. Pereira, and H. F. de Castro, "Immobilization of lipase on chitin and its use in nonconventional biocatalysis," Biomacromolecules, vol. 5, no. 1, pp. 17-23, 2004.

[24] A. A. Mendes, B. C. M. Barbosa, M. L. C. P. da Silva, and H. F. de Castro, "Morphological, biochemical and kinetic properties of lipase from Candida rugosa immobilized in zirconium phosphate," Biocatalysis and Biotransformation, vol. 25, no. 5, pp. 393-400, 2007.

[25] C. Airoldi and S. F. Oliveira, "Preparation, properties and ionic exchange behaviour of titanium (IV) arsenophosphate," Journal of the Brazilian Chemical Society, vol. 3, pp. 47-51, 1992.

[26] H. M. Aly, "The Al-13-phosphatoantimonic acid synthesis and ion exchange properties," Solvent Extraction and Ion Exchange, vol. 14, no. 5, pp. 947-954, 1996.

[27] Y. Yeşiloğlu, "Utilization of bentonite as a support material for immobilization of Candida rugosa lipase," Process Biochemistry, vol. 40, no. 6, pp. 2155-2159, 2005.

[28] F. Vaillant, A. Millan, P. Millan, M. Dornier, M. Decloux, and M. Reynes, "Co-immobilized pectinlyase and endocellulase on chitin and nylon supports," Process Biochemistry, vol. 35, no. 9, pp. 989-996, 2000.

[29] P. D. Desai, A. M. Dave, and S. Devi, "Alcoholysis of salicornia oil using free and covalently bound lipase onto chitosan beads," Food Chemistry, vol. 95, no. 2, pp. 193-199, 2006.

[30] S. Shah, S. Sharma, and M. N. Gupta, "Biodiesel preparation by lipase-catalyzed transesterification of Jatropha oil," Energy and Fuels, vol. 18, no. 1, pp. 154-159, 2004.

[31] E. Cambon, C. Bourlieu, T. F. C. Salum, G. Piombo, E. Dubreucq, and P. Villeneuve, "Ability of Vasconcellea $\times$ heilbornii lipase to catalyse the synthesis of alkyl esters from vegetable oils," Process Biochemistry, vol. 44, pp. 1265-1269, 2009.

[32] C. M. F. Soares, H. F. de Castro, M. H. A. Santana, and G. M. Zanin, "Intensification of lipase performance for longterm operation by immobilization on controlled pore silica in presence of polyethylene glycol," Applied Biochemistry and Biotechnology, vol. 98-100, pp. 863-874, 2002.

[33] C. M. F. Soares, H. F. de Castro, J. E. Itako, F. F. de Moraes, and G. M. Zanin, "Characterization of sol-gel bioencapsulates for ester hydrolysis and synthesis," Applied Biochemistry and Biotechnology, vol. 123, no. 1-3, pp. 845-859, 2005. 

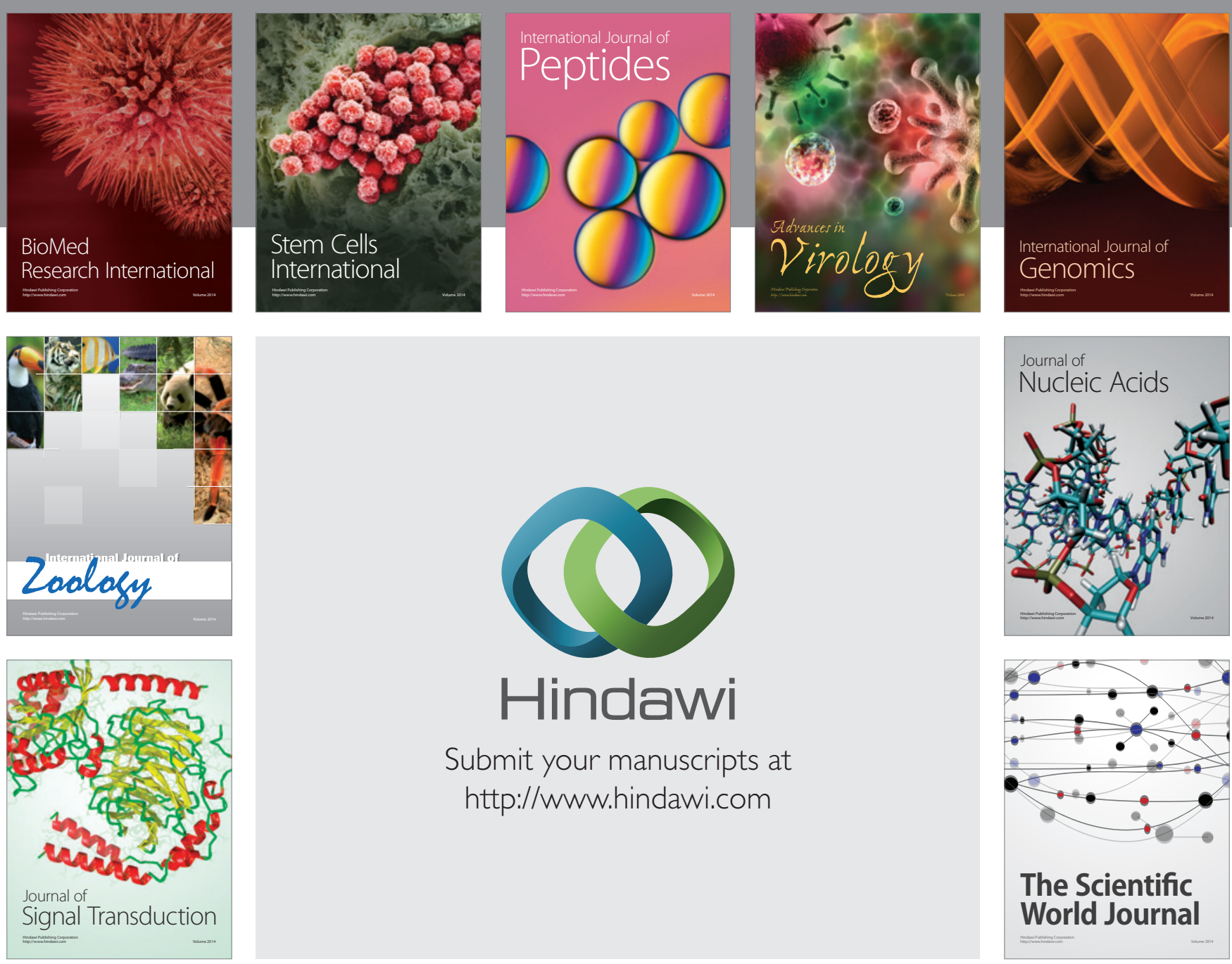

Submit your manuscripts at

http://www.hindawi.com
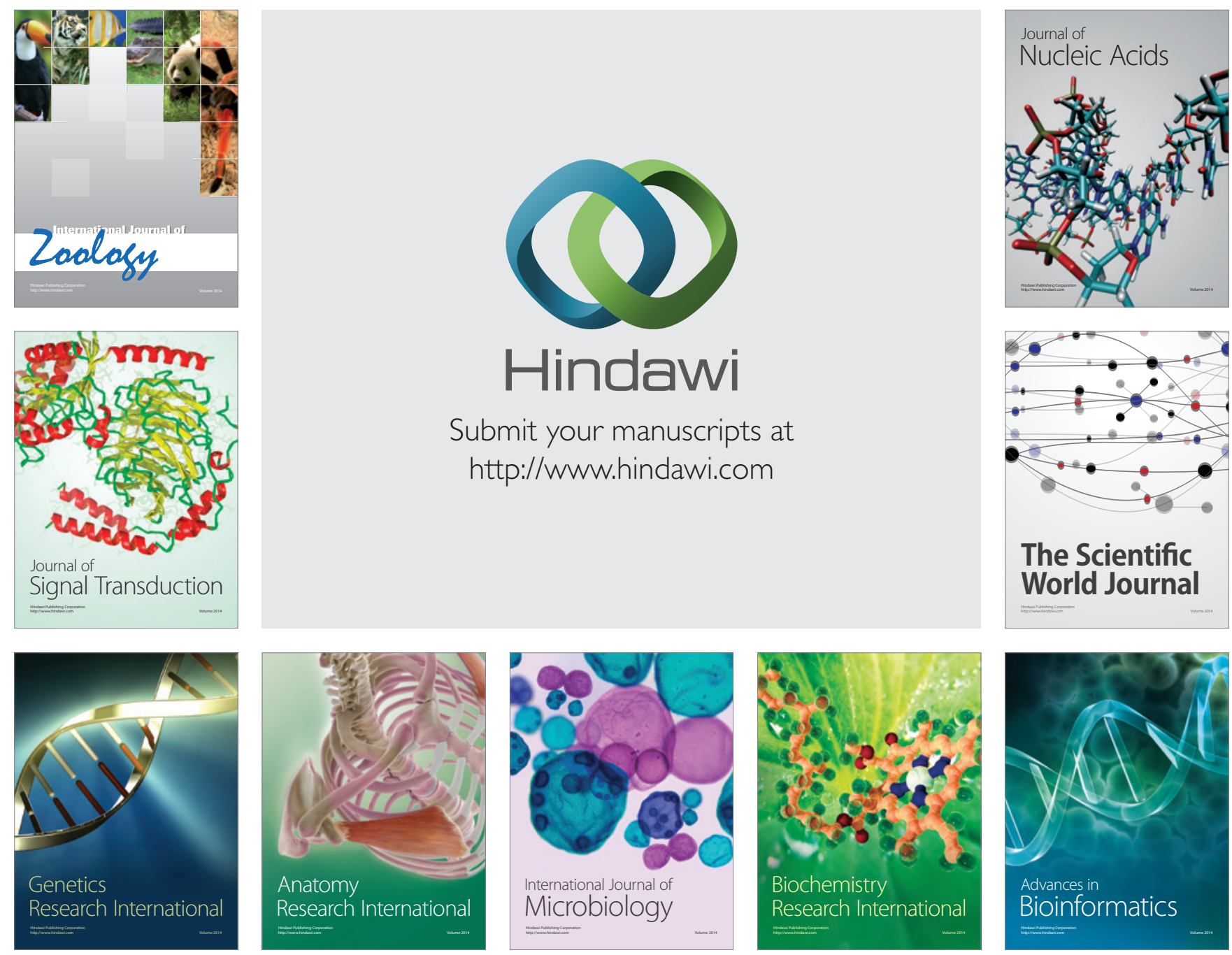

The Scientific World Journal
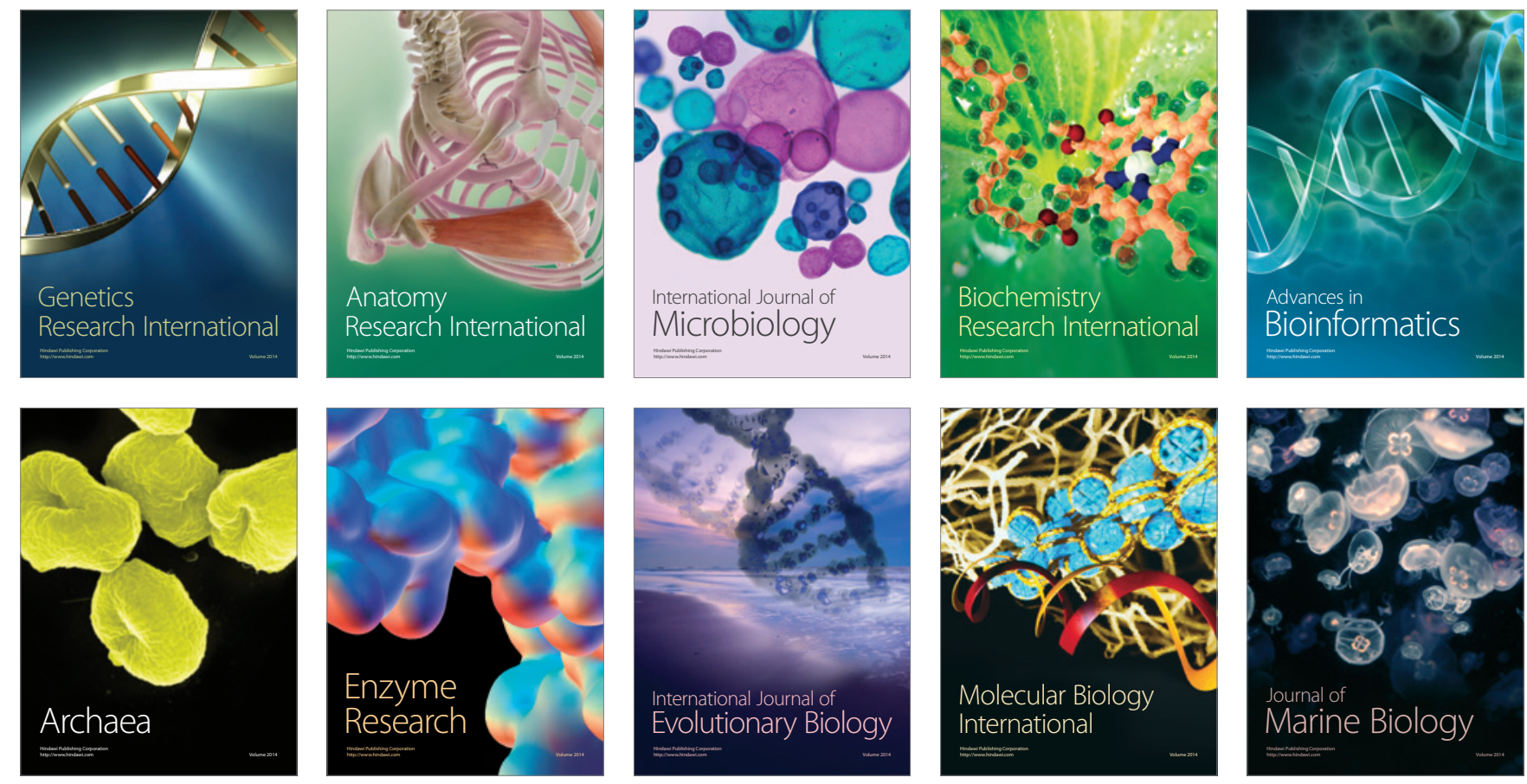